УДК 78.01/78.03+78.083

ORCID ID: 0000-0002-1969-5530

Овсяннікова-Трель Олександра Андріївна,

кандидат мистецтвознавства, доцент кафедри історії музики та музичної етнографії. Одеська національна музична академія ім. А. В. Нежданової,

Одеса

Овсянникова-Трель Александра Андреевна, кандидат искусствоведения, доцент кафедры истории музыки и музыкальной этнографии.

Одесская национальная музыкальная академия им. А. В. Неждановой,

Одесса

Alexandra Ovsiannikova-Trel,

Ph.D. in History of Arts, Associate Professor of History of Music and Musical Ethnography Department. Odessa National A. V. Nezhdanova Music Academy,

Odessa

\title{
ЛІРИЧНИЙ МОДУС ЖАНРОВОЇ СЕМАНТИКИ В КОНЦЕПЦЇ̈ «СЛАБКОГО СТИЛЮ» В. СИЛЬВЕСТРОВА
}

Анотація. Мета статті полягає у визначенні функціональних значень жанрово-семантичного рівня поетики інструментальних творів В. Сильвестрова, що репрезентує індивідуально-стильову специфіку композиторської концепції «слабкого стилю». Жанрово-інтонаційні метафори романсової лірики, якими користується композитор, розглядаються в комунікативному аспекті, що дає змогу визначати їх як основні чинники формування музичного смислу за допомогою спогаду про жанрово-семантичний образ романсу.

Ключові слова: музичний жанр, жанрова семантика, індивідуальний стиль, стилістика, метафора, музично-комунікативний модус.

Постановка проблеми та актуальність дослідження. Звернення до питань жанрової семантики сучасного музичного мистецтва зумовлене розвитком тих художньо-естетичних тенденцій, що породжують оригінальні версії композиторської творчості в умовах «ослаблення» стильового індивідуалізму як основного вектора історичної еволюції музичного професіоналізму. Зазначений напрямок композиторської практики, що представлений феноменом «нової простоти» і «слабкого стилю» В. Сильвестрова як оригінального прояву цієї стильової тенденції, становить невичерпний інтерес для музикознавства, бо його концептуальні підстави пов'язані 3 кореневими категоріями музики як виду мистецтва, які в умовах сучасної музичної творчості (композиторської, виконавської, слухацької) набувають універсального значення за допомогою суттєвого розширення свого змістовно-смислового потенціалу.

Серед таких категорій опиняються жанр і жанрова семантика: вони є основним інструментом формування музичного сенсу у творах композитора за допомогою «трансформації» їх в інтонаційні метафори та звукові образи музичного простору твору. Апелюючи до типових жанрів європейського музичного мистецтва, В. Сильвестров забезпечує відкритість глибинних смислів своєї музики для сучасного слухача. При цьому закономірним $€$ розширення і поглиблення музичного змісту, що формується в результаті функціонування того чи іншого типу жанрової семантики в принципово іншому соціально-культурному і музично-мовно- 
му контексті. Це питання не часто обговорюється в сучасних дослідженнях творчості українського композитора та не визначене як спеціальний предмет сучасного музикознавчого дискурсу; відповідно, звернення до нього відкриває можливості усвідомленого розуміння і сприйняття художньої концепції «слабкого стилю» В. Сильвестрова, що $\epsilon$ винятковим явищем сучасного музичного мистецтва.

Mema cmammi полягає у визначенні функціональних значень ліричного модусу жанрової семантики в поетиці інструментальних творів В. Сильвестрова в аспекті репрезентативності індивідуальної композиторської концепції «слабкого стилю».

Аналіз останніх досліджень $і$ публікацій. Філософсько-естетичні та музикознавчі аспекти стильових засад композиторської творчості на зламі XX-XXI століть у руслі «нової простоти» розглядалися К. Дальхаузом, Т. Чередніченко, М. Катунян, М. Булошніковим, В. Грачовим, М. Гайковіч, О. Токун, Н. Ручкіною, Н. Лівою, I. Коноваловою. У дослідженнях зазначених авторів визначені ключові позиції композиторського мислення, які зумовили ідею спрощення музичної мови в якості актуальної тенденції розвитку європейського музичного академізму від 1970-х років. У цьому контексті позначені і творчі установки В. Сильвестрова, що визначили специфіку його індивідуально-авторського стилю (дослідження Т. Чередниченко, М. Булошніков, Д. Жалейко, Н. Зимогляд, I. Коханик, Ю. Фурдуй). Питання жанрової семантики не представлені як спеціальний предмет музикознавчого інтересу зазначених авторів і через це заслуговують на окрему увагу, оскільки $є$ безумовними чинниками унікальної стильової концепції композитора. Для музикознавчого осмислення феномену «слабкого стилю» В. Сильвестрова істотними виявляються численні висловлювання самого композитора, які зафіксовані в таких виданнях, як «Музика — це спів світу про самого себе ... Бесіди, статті, листи», «Дочека-

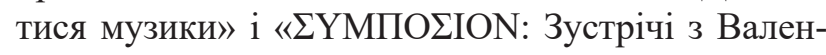
тином Сильвестровим». Зазначені джерела є тими матеріалами, що безпосередньо представляють слово Автора, у якому міститься суб'єктивно-особистісне вербальне вираження художньо-естетичних принципів музичної творчості. Цей вислів «від першої особи» $€$ найбільш цінним для теоретичної концептуалізації стильових характеристик музики українського композитора.

Виклад основного матеріалу. Ідея повернення до тональності й мелодії як до втраченої «при- роди музики» (Булошніков, 2010, с. 7) зумовила появу таких оригінальних індивідуально-композиторських версій «нової простоти», як «слабкий стиль» В. Сильвестрова: сам композитор визначає його ідею як «... не тільки “знайомий матеріал”, який має на собі печатку авторського самозречення. Це відмова від “активізму” на рівні становлення форми, відмова від дублювання “драми життя”, наслідком чого стає певне перебування в зоні коди» (там само, с. 8). Як «знайомий матеріал», у творах В. Сильвестрова часто виступає жанрова визначеність музичного тематизму, що викликає в пам'яті образно-змістовні асоціації, пов'язані $з$ усталеною в європейській музичній традиції жанровою семантикою.

За всієї відмінності точок зору на жанрову природу музики, представлених у сучасному музикознавчому дискурсі, існує загальний момент, який визнається більшістю істориків і теоретиків музичного мистецтва: музичний жанр, спочатку пов'язаний 3 конкретною життєвою ситуацією i тим життєвим контекстом, що визначив його функцію і призначення в житті людини, є соціально обумовленим і психологічно вмотивованим явищем. Саме тому музикознавці називають жанр «життєвою віссю» музики (Холопова, 2000, с. 218), «генетичною структурою», що відображає конкретний «ситуативний комплекс» (Назайкинський, 2003). У музикознавчій жанровій теорії склалася диференціація музичних жанрів, що спирається на змістовний і функціональний критерії - тобто на конкретний тип образності, який закріпився за тим чи іншим жанром, а також на його місце і роль у музичній практиці суспільства. До того ж функціональна сторона жанру може розглядатися як своєрідний словник, деякий набор лексем, що є специфічними для того чи іншого жанру і зберігаються за ним у процесі його історичної еволюції. У Є. Назайкинського з цього приводу знаходимо дуже важливу думку, що безпосередньо стосується жанрових витоків музичного змісту:

<...> при перенесенні повсякденної, побутової музики в концертний зал ця пам'ять жанру пам'ять про первинні ситуації, що його породили, - виявляється важливим 3 художньої точки зору змістовним, смисловим компонентом. Але навіть якщо таких слідів немає, музичний матеріал жанру в свідомості слухачів, виконавців, учасників комунікації вступає в міцний асоціативний зв'язок із жанровою ситуацією. I тоді, вже в інших обставинах і умовах, навіть в іншому історичному контексті, він починає виконувати функцію нага- 
дування (тут і далі курсив наш. - O. О.) про ті колишні ситуації і викликати певні, забарвлені спогадами, естетичні переживання. (Назайкинський, 2003, c. 138)

Відповідно, жанрові показники музичного твору мають стійку типовість - образно-змістовну і музично-мовну, - закріплену в колективній свідомості. Ця типовість зазвичай і викликає конкретні смислові асоціації, пов'язані з конкретикою музичного змісту. На думку Д. Кірнарської це забезпечує процес формування жанрів як «музично-комунікативних архетипів», тобто специфічних базисних форм музичного змісту, пов'язаних 3 протоінтонаційною формою музики: «Вони являють собою первинний рівень сприйняття музичного змісту, що спирається на комплекс неспецифічних музичних засобів недискретного характеру» (Лазутіна, 2009, с. 123). 3 цієї форми і походять поняття жанрової семантики, жанрового стилю і жанрового архетипу, що вміщують у своє змістовне поле як специфіку музичної мови (структурні та художньо-виразні характеристики), так і образно-змістовний компонент музичного твору і набувають особливої актуальності для розуміння авторської концепції інструментальних творів В. Сильвестрова.

Відомі «тихі» опуси композитора («Тиха музика» i «Спогади III», наприклад) яскраво ілюструють естетику «нової простоти», пов'язану зі спрощенням музичної мови: в концепції «слабкого стилю» простота музики виникає в результаті глибоко оригінального ставлення автора до популярних жанрів європейської музичної традиції (вальс, романс, серенада). У «Спогадах» для струнного оркестру та фортепіано жанрово-інтонаційною метафорою поруч з вальсом виступає російський романс (при цьому жодна 3 п'яти частин композиції не позначена автором як романс чи вальс). Основна виразна функція належить мелодичному профілю циклу, фрагменти якого буквально «дослівно» відтворюють інтонаційний словник російської пісенної лірики XIX ст. Спрощення стилю подібних опусів В. Сильвестрова реалізується композитором шляхом введення в музичну мову «популярних» мовних зворотів: маються на увазі загальновідомі інтонаційно-мелодійні формули, які є гранично конкретними у своїй жанрової приналежності й якими композитор користується як «будівельним матеріалом» музичної композиції. Упізнаваність їх культурною пам'яттю слухача забезпечує принцип доступності сприйняття ї семантичних властивостей, виразного потенціалу, в кінцевому рахунку — художнього сенсу, який формується за допомогою жанрової семантики. Л. Казанцева, розмірковуючи про музичні архетипи, зазначає, що для них істотними є дві позиції:

відображення закономірностей музичного та немузичного самовираження людини і спілкування людей, які залягають глибоко в свідомості; типологічна повторюваність і разом 3 тим індивідуальне відтворення в одиничних опусах. <...> зароджуючись в одиничних музичних висловлюваннях, смисли-архетипи адаптуються в наступних фазах історії музичної культури, корегуючи образно-художній світ музичних творів, тобто впливаючи на музичний зміст. (Казанцева, 2006, с. 78-79)

Особлива манера авторського інтонування «банального» жанрового матеріалу в «Спогадах» викликає до життя художню ідею інтонаційної метафори: принципова авторська відстороненість від індивідуалізму творчої інтерпретації жанрової моделі створює ефект «погляду збоку» на семантичний потенціал романсу, серенади, вальсу i породжує його нові смисли в контексті сучасності - як музичної, художньо-естетичної, так і світоглядної взагалі. Як вальс, так і романс, що $\epsilon$ репрезентантами популярної європейської музики XIX ст. (й більш ранніх історичних епох), мають стійкий музично-комунікативний модус, що відтворює певний тип усвідомлення людиною зв'язків і відносин з самим собою у формі ліричного переживання і висловлювання (аналогічно 3 драмою як формою відносин з людьми і епосом як формою відносин із зовнішнім світом). Саме ця спрямованість на суб'єктивність ліричного висловлювання визначає специфіку протоінтонації зазначених музичних жанрів як джерела «інтонаційного словника смислів» (Медушевський, 1993, с. 17) - тих первинних музичних модусів, які, будучи обумовлені психологією переживання, забезпечують емоційний тонус музичної мови і формують іiі смислові значення, закріплені в жанровій семантиці: «Романс у музиці, втім, як і вальс, - символ ліричних переживань героя. Елегія, ноктюрн, серенада також більш зручні при показі сфери інтенсивних почуттів, глибоких переживань». (Лазутіна, 2009, с. 126 ). Зазначений комунікативний модус виявився надзвичайно актуальним для композиторської практики 3 найдавніших часів у іiі спрямованості до індивідуалізму творчого самовираження (про що свідчать світські жанри Середньовіччя і Ренесансу) і досяг свого апогею в музичному романтизмі. А жанрова семантика вальсу, романсу і серенади, що склалася в історії європейського музичного мистецтва, активно використовувалася і композиторами XX 
ст. - саме в силу своєї смислової визначеності та конкретності.

У зазначеному контексті вальс можна розглядати як музично-пластичний архетип інтимного спілкування, а російський романс — як жанровий архетип лірико-сповідальної суті музики, символ індивідуально-суб'єктивного вираження особистості. На думку І. Гендлер, російський романс як популярний жанр був музично-поетичним атрибутом провінційного дозвілля XIX — початку XX ст. (Гендлер, 2012, с. 41), що вказує на принципову похідність специфіки цієї музично-комунікативної форми від повсякденної свідомості ії творців і ситуативного комплексу буденності. Дуже доречно в цьому разі звучить думка дослідниці феномену російського романсу про те, що романс став «деякою універсальною мовою любовних відносин» (там само, с. 41), бо вона спирається на глибинне розуміння жанрової семантики:

Романс - це гра в ідеальний час, в ідеальну історію, сенс якої - не уявна безпроблемність, а можливість повно і яскраво пережити зображений у творі епізод. Ліричний герой романсу за законом жанру має відому сміливість: йому доводиться говорити про сокровенне, інтимне - почуття любові, і стиль цих зізнань характеризується властивою саме романсу гармонією щирої відкритості й стриманої гідності. Основне почуття, що його відчуває персонаж романсу, крім любові, - це подяка. Комунікативною метою романсу не може бути жалість адресата або спроба повернути коханого. Герой чітко розуміс незворотність минулого і тому, хоч як парадоксально, романс відрізняється реалістичністю, прийняттям дійсного стану речей, про який, хоч як би сумно було, йдеться риторично ідеально. Подяка за любов і щастя, що пішли - романсовий варіант гідного прийняття життєвих потрясінь. (Гендлер, 2012, с. 43)

У такій об' ємній цитаті міститься дуже важлива вказівка на той сенс ліричного висловлювання, який розширює змістовні горизонти романсової лірики і виводить їх за рамки тривіальності «душевних виливів», наближаючи до високого етичного змісту серйозної музики.

У цьому ж смисловому контексті можна розглядати і серенаду, музичний жанр, за яким міцно закріпилося значення «любовної пісні» і який 3 часів куртуазного стилю трубадурів і труверів був освячений ідеєю лицарського служіння піднесеному Коханню. 3 огляду на той факт, що жанровий генезис серенади в європейській музиці був пов'язаний переважно $з$ аристократичним середовищем, полум'яність вираження любовного по- чуття в ній завжди корегувалася прийнятими нормами етикету і вишуканістю високого поетичного стилю. I хоча головний музично-комунікативний сенс цього жанру пояснюється його «включеністю в певний ритуал - захоплення, залицяння, освідчення в коханні» (Желнова, 2010, с. 22), він завжди мав вигляд «піднесеної емоції», що втілює щирість інтимного почуття і прагнення Автора до натхненності його вираження.

У художньому контексті розвитку музичного професіоналізму сучасності і вальс, і серенаду, й романс можна розцінювати як музичні образи втраченого ідеалу Краси почуттів, які можуть функціонувати в музичному тексті як метафоричні елементи. Але в концепції самого В. Сильвестрова йдеться не про втрачене Прекрасне, а лише про той стан культури і людини, який породжує відчуття цієї втрати. Жанрово-інтонаційні метафори в цьому разі виконують найважливішу комунікативну функцію, яка самим композитором мислиться таким чином: «для того, щоб сказати інакше, потрібно сказати те ж саме. Тут зв'язок 3 метафоричністю. Коли ти говориш те ж саме, але 3 певним індексом, то виникає якийсь натяк або знак, що ти говориш щось інше». (Сильвестров, 2012, с. 122). Авторське «говоріння» В. Сильвестрова здійснюється за допомогою загальновідомих і типових жанрів, наявних у культурній (і музичній відповідно) пам'яті європейського композитора і слухача поза індивідуально-авторськими ярликами, і мають стійку семантику. Саме тому воно є доступним для сприйняття і продуктивним для творчої інтерпретації, що також можна пояснити і тією обставиною, що саме поняття популярного містить не стільки «звернення до людей», скільки «щось набагато більш обтрунтоване (курсив наш - О. О.) в людях» (Middleton, 1993, с. 181). У подібному дусі міркує і В. Сильвестров, говорячи про щось невигубне в простих мелодіях популярної музики (Сильвестров, 2012 ).

Як бачимо, це обтрунтоване і незнищенне як те, що властиво людській свідомості й, власне, становить суть людської природи - актуалізується у «тихих» опусах В. Сильвестрова за допомогою простоти музичної мови (в сенсі ііі банальності і тривіальності). Цей факт дає змогу говорити про принципові відмінності художніх прагнень сучасної «простої» музики від тих позицій мистецтва XX ст., про які свого часу писав Ж. Бодрійяр:

Зникло мистецтво в сенсі символічної угоди, що відрізняє його від чистого і простого виробництва естетичних цінностей, відомого нам під ім'ям культури - нескінченного поширення зна- 
ків, рециркуляції минулих і сучасних форм. Немає більше ні основного правила, ні критерію судження, ні насолоди. (Бодрійяр, 1990)

Ці відмінності пов'язані, насамперед, з очевидністю тієї «символічної угоди», що наявна в музичній поетиці індивідуально-композиторських версій «нової простоти» як основний принцип музичного сенсу. Цей принцип у кожному окремому випадку реалізує ідею музичної мови як універсального феномену, здатного відобразити актуальний стан людської самосвідомості і здійснити в художній формі відповіді на нагальні питання свого часу.

Питання лише в тому, що зазначена Ж. Бодрійяром символічна природа мистецтва існує сьогодні за іншими законами, за іншими «правилами гри», які дають підстави говорити про новий тип композиторського мислення, що оперує, з одного боку, масштабним обсягом модусів музичної мови, сформованих у багатовіковій історії музичного мистецтва, з іншого - чітким усвідомленням смислової нескінченності цих модусів, що здатна відтворюватися в звуковій формі. В цьому, власне, і полягає «основне правило»: сучасний Автор «простої» музики не спрямований до реалізації творчого індивідуалізму, але прагне до відтворення того типу музичної мови та музичної виразності, які дають можливість існування Музики в «чистому вигляді»: в тих формах ідеальних звукообразів, які не обтяжені інтелектуальним й естетичним концептуалізмом епохи композиторських стилів і які спочатку були породжені вібраціями внутрішнього життя людської душі. Тобто йдеться не про те, щоб додати музичній мові свіü, «авторський» вид, підпорядкувати її своєму особистісному мовному модусу, а навпаки, «вилучити» Музику з прокрустова ложа творчого індивідуалізму і дати їй можливість бути «співом світу про самого себе» (за відомим формулюванням В. Сильвестрова).

У такому антропологічному вимірі популярні елементи музичної мови В. Сильвестрова набувають особливої смислової глибини і ємності, оскільки вони реалізують іманентний зв'язок музики з емоційним досвідом людини, про який пише О. Самойленко, в зв'язку з мелодраматичною сутністю масових музичних жанрів:

Масові, прикладні, повсякденні, напівпрофесійні, аматорські жанри <..> створюють звичку емоційного реагування, включають індивідуальний емоційний досвід у загальноприйнятий, виробляють типізовані форми переживання і так далі. Можна сказати і різкіше: масові жанри в усіх видах мистецтва звернені до досвіду банального, без якого не було б і оригінального. Можливий $\mathrm{i}$ зворотний взаємозв'язок, за яким припускаємо, що банальне - це оригінальне, яке стало повсюдним. (Самойленко, 2020, с. 27)

Зазначена О. Самойленко функція масових жанрів стає основною смисловою координатою згаданих творів В. Сильвестрова: банальність і тривіальність романсової, вальсової і серенадної інтонації є метафорою почуття, або навіть здібноcmi до почуття і щирості його вираження - тобто тих якостей міжособистісних відносин, які можна розцінювати як атрибут романтизму, які дедалі більше «стираються» в соціальному житті сучасної людини і без яких сумнівною видається подальша доля людства і мистецтва. Доречною з цього приводу є думка I. Гендлер, яка, говорячи про комунікативний аспект російського романсу в контексті сучасної культури, стверджує наступне:

Романс, всупереч стереотипному уявленню про нього як про просту шаблонну любовну пісню, зачіпає різні сторони людських відносин. При всій клішованості романсної мови, твори цього жанру характеризуються дивовижною делікатністю в зображенні інтимних переживань, точністю визначень в описі відтінків почуття, щирістю захопленого і радісного сприйняття навколишнього світу. Все це виражено мовними засобами, які сучасною людиною ще розуміються, але вживаються дедалі рідше, оскільки, будучи елементами безпосереднього спілкування, вони не можуть вписатися в контекст популярного нині спілкування дистантного. Однак саме в романсі ці цінності зберігаються не у вигляді абстрактних незрозумілих фраз, а як яскрава, жива стихія спілкування небайдужих одне до одного людей, які вміють показати свої почуття, наголосити важливість діалогу і висловити це ідеальною мовою, яка багато в чому і створює ідеальні, тобто повні, глибокі, щирі відносини. (Гендлер, 2012, с. 46)

На завершення відзначимо, що ще на початку $\mathrm{XX}$ ст. Валерій Брюсов, розмірковуючи про природу банального, говорив про ту форму ставлення людини до банального, яка дивним чином співзвучна сучасним композиторським установкам на спрощення музичної мови:

На нижчому щаблі розвитку людина не знає нічого, крім банального: визнає тільки загальновизнане, говорить тільки загальновідоме. На вищому щаблі розвитку людина уникає банального, шукає оригінального, насолоджується тим, що не банально. Але є ще більш високий рівень: на ньому стоять люди, які говорять не тільки для свого часу, але і для 
майбутнього: вони вміють вибирати з банальних істин такі, які для інших часів знову стануть потрібними, важливими, оригінальними. (Брюсов, 1920)

У цьому спостереженні міститься глибоке розуміння творчого мислення, яке за допомогою художнього перетворення традиційних форм i мовних засобів мистецтва здатне формувати його нові ціннісні смисли і «відповідати» на актуальні для свого часу питання про сенс людського життя. Якщо розглядати обговорювані вище жанри музичного мистецтва як «банальні істини» європейської музичної історії (вальс, романс, серенада), a їх жанрово-комунікативний сенс як «банальні істини» людського існування, то 3 упевненістю можна стверджувати, що звернення до них сучасних композиторів пов'язане винятково з прагненням осмислити сучасний стан людської свідомості і запропонувати свій варіант «відповіді». Причому у випадку з В. Сильвестровим ця «відповідь» більш ніж «оригінальна, важлива і потрібна»: композитор, створюючи звукові образи своїх творів на основі типової музичної лексики, керується установкою, яку одного разу дуже переконливо сформулював: «це дуже важливо: не боятися банальності. У банальності хоч і $є$ своя небезпека, але боязнь банальності - це нова банальність, ще страшніша. Банальними $\epsilon$, наприклад, почуття, щирість<...> (Сильвестров, 2012, с. 73).

Така авторська позиція парадоксальним чином перетинається з думкою Ж. Бодрійяра про $б a-$ нальне як про той предмет мистецтва, що замінює в сучасній версії естетичних категорій піднесене старої культури (Бодрійяр, 1990). I хоча артефакти, що представляють банальне в розумінні французького філософа-постмодерніста і українського композитора, принципово різні (але в обох випадках вони відносяться до художнього простору популярної культури), їхня функція «відшкодування відсутнього» очевидна: вони є тим фактором, що компенсує втрачену гармонію. В цьому разі особливий етичний сенс набуває творча і людська позиція В. Сильвестрова, яка, втілившись у його «слабкому» або «неактуальному» композиторському стилі, закликає нас почути в звучанні його музики вічно актуальні для людини істини, про які свого часу писав О. Лосєв:

$<\ldots>$ тільки в музиці, стаючи обличчям до обличчя життя, ми бачимо всю нашу повсякденну схильність до абстракції і бачимо, як все просте і ясне в переживаннях пов'язане глибокими містичними коріннями зі Світовою Душею, що б'ється в кожній маленькій людській особистості. (Лосєв, 1995, с. 318)
Тривіальність музичної мови вальсу, романсу i серенади, що виступає центральним елементом стилістики зазначених опусів В. Сильвестрова, також можна розглядати як яскравий приклад мнемонічної функції музичного мистецтва і музичного жанру, яка обговорюється в монографії О. Самойленко:

$<\ldots>$ ця функція пов'язана 3 тим полюсом культурної пам'яті, який відповідає за переклад у новий смисловий контекст знаків і значень та оновлення цінностей, і саме фактор спогаду виступає в даному випадку в якості основного «знаряддя» формування значень. (Самойленко, 2020, c. 71,102$)$

Як бачимо, спогад як властивість людської пам'яті набуває значення вагомого чинника буття музики в світі людей та іï еволюційних процесів. А спогад як музичний образ має значний потенціал самовираження людини в музиці, компенсуючи відсутність «відсутніх ланок» у повсякденної реальності. Однак найбільш важливим стає розуміння спогаду як інструменту здобуття істини, функцію якого в творах В. Сильвестрова на себе бере жанрова семантика. У цьому разі музика, згадуючи своє минуле, знаходить в оригінальних формах «... ще небачені образи, і при цьому викликає «минулі» - людські - почуття і думки» (Акопян, 2005, с. 325), а людина, зустрічаючись 3 цими образами, згадує про головне, про те, що, власне, і робить її людиною.

Висновки. У композиторській концепції «слабкого стилю» істотним $є$ звернення до «знайомого матеріалу», в якості якого у розглянутих інструментальних творах В. Сильвестрова виступає жанрова визначеність звукового образу, що викликає в пам'яті слухача конкретні образно-змістовні асоціації. Останні пов'язані з усталеною в європейській музичній традиції жанровою семантикою, яка визначає образно-змістовну і музично-мовну типологію жанрового розмаїття музичного мистецтва і забезпечує процес формування жанрів як музично-комунікативних модусів, що є істотними для розуміння художньої концепції творів В. Сильвестрова. Спрощення музичної мови як «ослаблення» стилю реалізується в «Тихій музиці» $\mathrm{i}$ «Спогадах» за допомогою введення в музичну мову «популярних» зворотів інтонаційно-мелодійних формул вальсу і романсу (а також алюзій на «Серенаду» Ф. Шуберта), які в європейській музиці персоніфікують ліричний модус музичного вираження. Саме цей вектор сприйняття жанрового змісту об'єднує семантичний потенціал романсу, серенади, вальсу і поро- 
джує його нові смисли в умовах сучасної художньо-естетичної реальності. Жанрово-інтонаційні метафори, якими користується композитор, в цьому разі виконують найважливішу комунікативну функцію, оскільки виступають тим елементом музичного тексту, який забезпечує впізнаваність музичного смислу за допомогою спогаду про його жанрово-семантичний образ, що живе в пам'яті культури. «Банальність» романсової і вальсової інтонацій в такому разі є метафорою здатності до почуття і щирості його вираження як тих якостей міжособистісних відносин, що їх можна розцінювати як атрибут «минулого» людської історії, оскільки вони дедалі більше «стираються» в соціальному житті сучасної людини. У такому вимірі жанрова семантика в концепції композиторського стилю В. Сильвестрова набуває особливого функціонального значення: вона $є$ тим компонентом музичної поетики, що реалізує іманентний зв'язок музичного мистецтва 3 емоційним досвідом людини, переживання якого виявляється надзвичайно актуальним для сучасного людства.

\section{Бібліографія}

Акопян, К. (2005). ХХ век в истории искусства (История болезни как повод для размышлений). Москва: Академический Проект: РИК. 336 с.

Бодрийяр, Ж. (1990). Прозрачность зла. Глава 2. Трансэстетика. Гуманитарный портал. Відновлено $3 \mathrm{https:/gtmarket.}$ $\mathrm{ru} /$ laboratory/basis/3413/3415

Брюсов, В. (1920). Miscellanea. Замечания, мысли о искусстве, о литературе, о критиках, о самом себе. Відновлено 3 https:/www.litmir.me/br/?b=551099\&p=2

Булошников, М. (2010). Валентин Сильвестров вчера и сегодня: к проблеме «слабого стиля». Актуальные проблемь высшего музыкального образования. Нижний Новгород: Нижегородская государственная консерватория им. М. И. Глинки. № 1. С. 6-8.

Гендлер, И. (2012). Русский романс в современной культуре как воплощение идеальной речи. Cuadernos de Rusística Española. № 8. С. 39-46. Відновлено 3 https://revistaseug. ugr.es/index.php/cre/article/viewFile/55/54

Желнова, Ю. (2010). Приватное музицирование в России XVIII - первой половины XIX века: к проблеме адаптации жанра серенады. Южно-Российский музыкальный альманах. Ростов-на-Дону: РГК. № 1(6). С. 21-25.

Казанцева, Л. (2006). Род как архетип музыкального содержания. Южно-Российский музыкальный альманах - 2005. Ростов-на-Дону: РГК. С. 78-85.

Лазутина, Т. (2009). Символичность музыкального жанра. Вестник Томского государственного университета. № 324, июль. Томск: ТГУ. С. 123-126.

Лосев, А. (1995). Форма-Стиль-Выражение. Москва: Мысль. $944 \mathrm{c}$.

Медушевский, В. (1993). Интонационная форма музыки. Москва: Композитор. 262 с.

Назайкинский, Е. (2003). Стиль и жанр в музыке. Москва: ВЛАДОС. 248 с.

Самойленко, О. (2020). Психологія мистецтва: сучасні музикознавчі проекції: монографія. Одеса: Видавничий дім «Гельветика». 236 с.
Сильвестров, В. (2012). Дождаться музыки. Лекции-беседы. По материалам встреч, организованных Сергеем Пилютиковым. Киев: ДУХ І ЛІТЕРА. 368 с.

Холопова, В. (2000). Музыка как вид искусства: учебное пособие. Санкт-Петербург: Лань. 320 с.

Middleton, R. (1993). Popular Music Analysis and Musicology: Bridging the Gap. Popular Music, Vol. 12. No. 2. Pp. 177190. Cambridge University Press.

\section{References}

Akopyan, K. (2005). XX vek v istorii iskusstva (Istoryia bolezny kak povod dlia razmishlenyi) [XX century in the history of art (History of the disease as a reason for reflection)]. Moskva: Akademycheskyi proekt. [in Russian]

Baudrillard, J. (1990). Prozrachnost zla. Glava 2. Transestetyka [Transparency of evil. Chapter 2. Transaesthetics]. Gumanytarniy portal. URL: https://gtmarket.ru/laboratory/ basis/3413/3415 [in Russian]

Bryusov, V. (1920). Miscellanea. Zamechanyia, misly o iskusstve, o lyterature, o krytykakh, o samom sebe [Miscellanea. Comments, thoughts about art, about literature, about critics, about oneself]. URL: https://www.litmir.me/br/?b=551099\&p=2 [in Russian]

Buloshnikov, M. (2010). Valentyn Sylvestrov vchera y sehodnia: k probleme "slaboho stylia» [Valentin Silvestrov yesterday and today: to the problem of "weak style"]. Aktualnie problemi visshego muzikalnogo obrazovanyia.

Nyzhnyi Novgorod: Nyzhegorodskaia gosudarstvennaia konservatoryia im. M. I. Glynky. № 1. S. 6-8. [in Russian]

Gendler, I. (2012). Russkiy romans v sovremennoy kulture kak voploschenie idealnoy rechi [Russian romance in modern culture as the embodiment of ideal speech]. Cuadernos de Rusística Española. №. 8. S. 39-46. URL: https://revistaseug. ugr.es/index.php/cre/article/viewFile/55/54 [in Russian].

Zhelnova, Y. (2010). Privatnoe muzitsirovanie v Rossii XVIII pervoy polovinyi XIX veka: $\mathrm{k}$ probleme adaptatsii zhanra serenadyi [Private music making in Russia in the 18th - first half of the 19th century: on the problem of adapting the serenade genre]. Yuzhno-Rossiyskiy muzyikalnyiy almanah. Rostov-na-Donu: RGK. № 1(6). S. 21-25. [in Russian]

Kazantseva, L. (2006). Rod kak arhetip muzyikalnogo soderzhaniya [The kind as an archetype of musical content]. Yuzhno-Rossiyskiy muzyikalnyiy almanah. Rostov-na-Donu: RGK. S. 78-85. [in Russian]

Lazutina, T. (2009). Simvolichnost muzyikalnogo zhanra [Symbolism of the musical genre]. Vestnik Tomskogo gosudarstvennogo universiteta. № 324, iyul. Tomsk: TGU. S. 123-126. [in Russian]

Losev, A. (1995). Forma - Stil - Vyirazhenie [Form-Style-Expression]. Moskva: Myisl. [in Russian]

Medushevsky, V. (1993). Intonatsionnaya forma muzyiki [Intonational form of music]. Moskva: Kompozitor. [in Russian]

Nazaikinsky, E. (2003). Stil i zhanr v muzyike [Style and genre in music]. Moskva: VLADOS. [in Russian]

Samoilenko, O. (2020). Psykholohiia mystetstva: suchasni muzykoznavchi proektsii: monohrafiia [Psychology of art: modern musicological projections: monograph]. Odesa: Vydavnychyi dim «Helvetyka». [in Ukrainian]

Silvestrov, V. (2012). Dozhdatsya muzyiki. Lektsii-besedyi. Po materialam vstrech, organizovannyih Sergeem Pilyutikovyim. [Wait for the music. Lectures-conversations. According to the materials of the meetings organized by Sergei Pilyutikov]. Kiev: DUH I LITERA. [in Russian]

Kholopova, V. (2000). Muzyika kak vid iskusstva: uchebnoe posobie [Music as a kind of art: a tutorial]. Sankt-Peterburg: Lan. [in Russian]

Middleton, R. (1993). Popular Music Analysis and Musicology: Bridging the Gap. Popular Music, Vol. 12, No. 2 (May). Cambridge University Press. [in English] 


\section{Olexandra Ovsiannikova-Trel'}

\section{Genre semantics in the concept of «weak style» by V. Silvestrov}

Abstract. The purpose of the article is to determine the functional meanings of the genre-semantic level of poetics of V. Silvestrov's instrumental works in the aspect of the representativeness of the individual composer's concept of «weak style» in contemporary musical art. Genre-intonation metaphors used by the composer are considered in the communicative aspect, as they act as a factor in the formation of musical meaning through the recollection of its genre-semantic image.

Keywords: musical genre, genre semantics, individual style, stylistics, metaphor, musical and communicative mode.

\section{Овсянникова-Трель Александра Андреевна \\ Лирический модус жанровой семантики в концепции «слабого стиля» \\ В. Сильвестрова}

Аннотация. Цель статьи заключается в определении функциональных значений жанрово-семантического уровня поэтики инструментальных произведений В. Сильвестрова, который репрезентует индивидуально-стилевую специфику композиторской концепции «слабого стиля». Жанрово-интонационные метафоры романсовой лирики, которыми пользуется композиор, рассматриваются в коммуникативном аспекте, что дает возможность обозначать их в качестве основых факторов формирования музыкального смысла, памятуя о жанрово-семантическом образе романса.

Ключевые слова: музыкальный жанр, жанровая семантика, индивидуальный стиль, стилистика, метафора, музыкально-коммуникативный модус. 